\title{
ACCOUNTING FOR THE HETEROGENEITY IN RETIREMENT WEALTH
}

\author{
Fang Yang* \\ CRR WP 2009-6 \\ Released: March 2009 \\ Draft Submitted: January 2009
}

\author{
Center for Retirement Research at Boston College \\ Hovey House \\ 140 Commonwealth Avenue \\ Chestnut Hill, MA 02467 \\ Tel: 617-552-1762 Fax: 617-552-0191
}

* Fang Yang is an assistant professor in the department of economics at the University of Albany. The research reported herein was pursuant to a Sandell grant from the U.S. Social Security Administration (SSA) funded as part of the Retirement Research Consortium (RRC). The findings and conclusions expressed are solely those of the author and do not represent the views of SSA, any agency of the Federal Government, the RRC, SUNY-Albany, or Boston College.

(C) 2009, by Fang Yang. All rights reserved. Short sections of text, not to exceed two paragraphs, may be quoted without explicit permission provided that full credit, including (C) notice, is given to the source. 


\title{
About the Center for Retirement Research
}

The Center for Retirement Research at Boston College, part of a consortium that includes parallel centers at the University of Michigan and the National Bureau of Economic Research, was established in 1998 through a grant from the Social Security

Administration. The Center's mission is to produce first-class research and forge a strong link between the academic community and decision makers in the public and private sectors around an issue of critical importance to the nation's future. To achieve this mission, the Center sponsors a wide variety of research projects, transmits new findings to a broad audience, trains new scholars, and broadens access to valuable data sources.

\author{
Center for Retirement Research at Boston College \\ Hovey House \\ 140 Commonwealth Avenue \\ Chestnut Hill, MA 02467 \\ phone: 617-552-1762 fax: 617-552-0191 \\ e-mail: crr@bc.edu \\ www.bc.edu/crr
}

Affiliated Institutions:

The Brookings Institution

Massachusetts Institute of Technology

Syracuse University

Urban Institute 


\begin{abstract}
This paper studies a quantitative dynamic general equilibrium life-cycle model where parents and their children are linked by bequests, both voluntary and accidental, and by the transmission of earnings ability. This model is able to match very well the empirical observation that households with similar lifetime earnings hold very different amounts of wealth at retirement. Earnings heterogeneity and borrowing constraints are essential in generating the variation in wealth at retirement among low lifetime earnings households, while inheritance heterogeneity helps to generate the heterogeneity in wealth at retirement among high lifetime earnings households.
\end{abstract}




\section{Introduction}

Many papers document that households with similar characteristics, such as lifetime income, age, and family structure, hold very different amounts of wealth at retirement (see, among others, Hurst, Luoh and Stafford (1998), and Grafova, McGonagle and Stafford (2006)). Various economists (see, for example, Bernheim, Skinner and Weinberg (2001), and Hendricks (2007)) argue that this feature of the data is inconsistent with most life-cycle models of consumption-saving behavior, and thus constitutes a challenge to such theories and their policy implications.

In particular, Venti and Wise (2000) and Hendricks (2007) document that substantial wealth difference remains after controlling for lifetime earnings and age. At all levels of lifetime earnings, there is a large dispersion in the accumulated wealth at retirement: A significant fraction of high earnings households have relatively little wealth and a substantial fraction of low earnings households have a lot.

In this paper, I quantify how much of the observed heterogeneity in wealth at retirement can be generated by a realistically parameterized model with incomplete markets and earnings shocks. The model that I am using mainly incorporates two basic forces, bequests and human capital transmission, into an otherwise standard lifecycle model. ${ }^{1}$ In this model, households face uninsurable labor-income risk, uncertain lifetimes, and borrowing constraints in the bonds market. Households save to selfinsure against labor income shocks and life-span risk, for retirement, and possibly to leave bequests to their children. Households are ex-ante identical. Wealth inequality at retirement arises because households differ in the timing of earnings over the life cycle and in the amount and timing of inheritances received. ${ }^{2}$

\footnotetext{
${ }^{1}$ This model extends De Nardi (2004). It allows children to observe parents' states and incorporates a realistic Social Security system and a private pension system.

${ }^{2}$ I assume limited sources of heterogeneity, abstracting from ex-ante heterogeneity in wealth holdings by race (see for example Smith (1995), and Altonji and Doraszelski (2005)), by education (see for example Hubbard, Skinner and Zeldes (1995), and Cagetti (2003)), and by preference (see for example
} 
This incomplete-market model with earnings heterogeneity and inheritance heterogeneity can generate large wealth heterogeneity among households with similar lifetime earnings. I find that while differences in the timing of earnings shocks and borrowing constraints can generate large heterogeneity in wealth at retirement for households at lower lifetime earnings deciles, differences in the timing and amount of inheritance help to generate large heterogeneity in wealth at retirement for households at higher lifetime earnings deciles.

The existence of borrowing constraints prevents households from smoothing consumption intertemporally. Two households might have the same lifetime earnings, but one might have positive earnings shocks when young and negative earnings shocks when old while the other has negative earnings shocks when young and positive earnings shocks when old. At retirement, those two households will hold amounts of wealth that differ substantially.

Inheritance adds another source of wealth heterogeneity among households with similar lifetime earnings. Some earnings-poor households might have inherited a large amount of assets. With a voluntary bequest motive, those who have inherited keep a large amount of inherited assets to leave to their children, thus holding a substantial amount of wealth at retirement. Some earnings-rich households receive no inheritance and thus own less wealth.

The general equilibrium model with bequests and human capital transmission endogenously determines an inheritance distribution. In the data, inheritances are highly unevenly distributed. $50 \%$ of the households receive very little or no inheritance during their life time. The top $1 \%$ of the households receive $35 \%$ of all the inheritances. The model generates a skewed inheritance distribution that is comparable with the data.

Krusell and Smith (1998), Samwick (1998), and Hendricks (forthcoming)), from ex-post heterogeneity in wealth holdings by marital status (see for example Cubeddu and Rios-Rull (2003), and Guner and Knowles (2003)), by children (see for example Scholz and Seshadri (2006), and by rate of return (see for example Guvenen (2006)). 
Modeling transmission of earnings ability across generations and bequests as luxury goods is the key to generating a skewed distribution of inheritances.

I compare the benchmark model with models with one or no intergenerational links. A model with bequest motives and without intergenerational transfer of productivity generates more heterogeneity of wealth at retirement among households with similar lifetime earnings than the benchmark model. One reason is that, voluntary bequest motives are enough to generate a skewed inheritance distribution. Another reason is that, with an operative bequest motive, those who inherited large estates from their parents will keep a large part of their inheritances. Thus the heterogeneity of inheritance adds a lot to the heterogeneity of retirement wealth. The third reason is that, without intergenerational link of productivity, inheritances are evenly distributed by lifetime earnings decile. Some households at the low lifetime earnings deciles receive unrealistically large amount of inheritances, weakening the correlation between lifetime earnings and retirement wealth. A version without bequest motives shows that the unequal distribution of involuntary bequests and intergenerational transfer of earnings ability are not sufficient to generate the observed heterogeneity of wealth at retirement. One reason is that accidental bequests along are not enough to generate a skewed inheritance distribution. The other reason is that, without an operative bequest motive, those who have inherited large estates from their parents will consume a large part of their inheritances before retirement. Finally, in a model without intergenerational transfer of both bequests and earnings ability, the only source of heterogeneity is the timing of earnings shocks. The comparison indicates that the timing of earnings shocks and the existence of borrowing constraints along are not enough to generate the observed wealth heterogeneity among households with similar lifetime earnings.

This paper is related to the literature that examines the implications of different models on wealth dispersions at retirement age. Engen, Gale, Carroll and Laibson 
(1999), Engen, Gale and Uccello (2004), and Scholz, Seshadri and Khitatrakun (2006) study the adequacy of household retirement saving. Those papers abstract from the intergenerational links of bequests and earnings ability. Gokhale, Kotlikoff, Sefton and Weale (2001) abstract from voluntary bequest motives. Hendricks (2007) finds that while the qualitative implications of a model with earnings and inheritance differences are in line with the data, the quantitative implications are not. The key difference between my model and Hendricks's is in the treatment of bequests. Hendricks assumes all bequests are accidental; I assume households are altruistic towards their descendants. Hendricks assumes that households receive bequests at the same age; I assume that the time of inheritance is uncertain and different.

The paper is organized as follows. Section 2 presents some empirical results from Venti and Wise (2000) and Hendricks (2007) documenting heterogeneity of wealth at retirement among households with similar lifetime earnings. In Section 3, I present the model and the calibration of the model. In Section 4, I show the quantitative results of the benchmark model and investigate the importance of earnings heterogeneity and inheritance heterogeneity. Section 5 investigates the quantitative importance of intergenerational links. Section 6 presents conclusions.

\section{$2 \quad$ Empirical Findings}

This section presents some empirical results from Venti and Wise (2000) and Hendricks (2007) showing that, substantial wealth difference remains after controlling for lifetime earnings and age: Households with similar lifetime earnings hold diverse amounts of wealth at retirement age.

Venti and Wise (2000) use data from the Health and Retirement Study (HRS) for households whose heads were between age 51 to 61 in 1992. They use wealth of the household and lifetime earnings measured by historical earnings reported to Social 
Security Administration. They find that, at all levels of lifetime earnings, there is a large dispersion in the accumulated wealth at retirement. Very little of this dispersion can be explained by differences in individual circumstances that are out of the control of the households. They argue, informally, that the dispersion of wealth at retirement must be attributed to differences in the amount that households choose to save.

Hendricks (2007) uses data from the Panel Study of Income Dynamics (PSID) on wealth reported at age $65 .^{3}$ Earnings consist of labor income (net of income tax payments and Social Security contributions) received by the household head and by the spouse, which include wages, salaries, bonuses, overtime payments, and the business part of labor income. Lifetime earnings are the presented value of earnings between the ages of 18 and 65 , discounted to age 65.

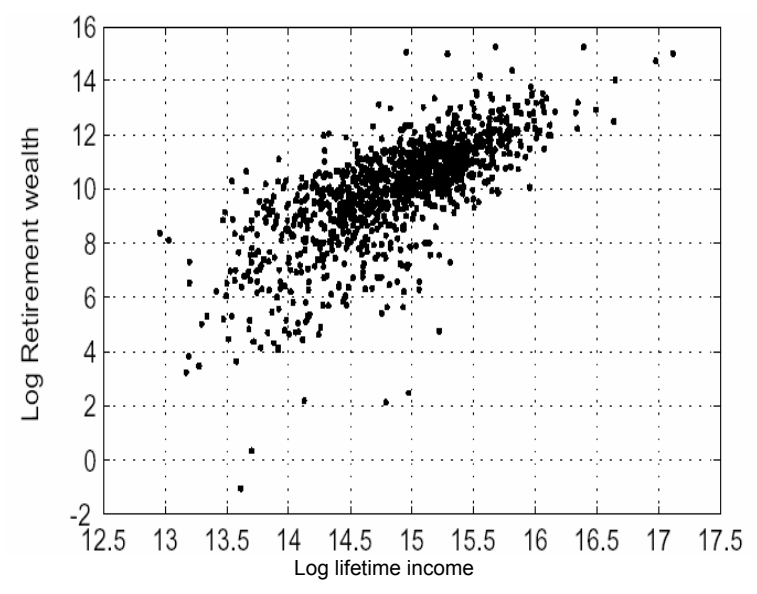

Figure 1: Retirement wealth and lifetime earnings in the PSID

Figure 1 shows the scattered plot of log retirement wealth and log lifetime earnings from PSID. Wealth at retirement is strongly correlated with lifetime earnings: The correlation coefficient between lifetime earnings and wealth at retirement is 0.61. However, at all levels of lifetime earnings there is large dispersion in the accumulated

\footnotetext{
${ }^{3}$ SCF has a better coverage of high-earner and high-wealth households than PSID and HRS. However, as is shown in Juster, Smith and Stafford (1999), and Cagetti (2003), for lower quartiles, those data sets give similar information.
} 
wealth at retirement: A significant fraction of high earnings households have relatively little wealth and a significant fraction of low earnings households have a lot.

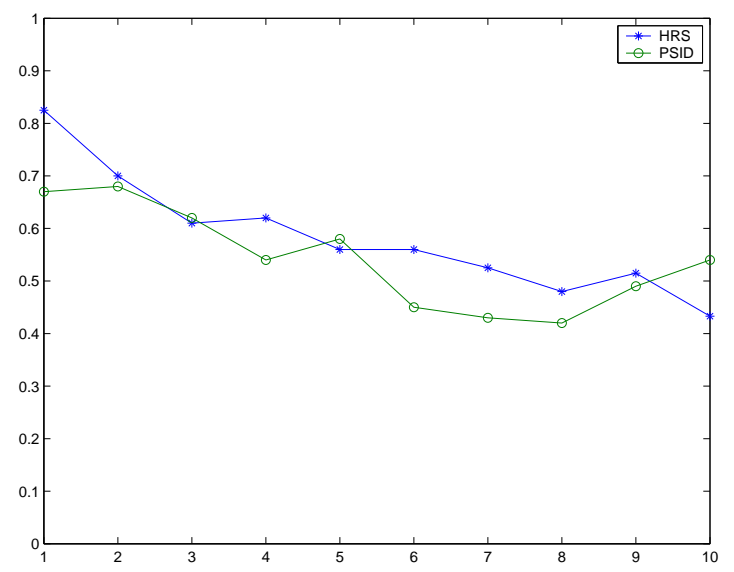

Figure 2: Gini coefficient of retirement wealth for each earnings decile

Figure 2 displays the Gini coefficient of retirement wealth for each lifetime earnings decile from Venti and Wise (2000) and Hendricks (2007). We observe that, controlling for age and lifetime earnings reduces wealth inequality. For example, in the PSID, the average of the Gini coefficients in wealth across lifetime earnings deciles is 0.54 , compared with 0.62 in the full sample. However, there is still large wealth inequality after controlling for age and lifetime earnings: The Gini coefficients are all above 0.4. The degree of wealth inequality declines with lifetime earnings decile.

To check the robustness of those findings, Venti and Wise (2000) conduct regressions to control for household characteristics. Hendricks (2007) restricts samples to contain only households with similar characteristics. The main findings are not affected by household characteristics such as numbers of children, marital breakups, self-employment, or stock holdings.

Those papers' findings thus indicate that households with similar lifetime earnings hold diverse amounts of wealth at retirement age, even when samples are restricted to exclude sources of wealth heterogeneity that are not related to earnings. Those features of the data constitute a challenge to our theories of saving behavior. 


\section{The Model}

The economy is a discrete-time overlapping generations world with an infinitely-lived government. There are idiosyncratic earnings shocks. These shocks are uninsurable: The only financial instrument is a one-period bond. Households cannot engage in unsecured borrowing; net assets must be non-negative. There is mortality risk but private annuity markets do not exist. ${ }^{4}$ Members of successive generations are linked by bequests and the children's inheritance of part of their parent's productivity. At age 20, each agent enters the model and starts consuming, working, and paying labor and capital income taxes. At age 35, the agent procreates. After retirement, the agent no longer works but receives interest from accumulated assets and benefits from defined benefit plan and Social Security. The government taxes labor earnings, capital income and estates, pays Social Security benefits to retirees, and provides government consumption.

\subsection{Demographics}

During each model period, which is 5 years long, a continuum of people is born. Since there are no inter-vivos transfers, all agents start their working life with no assets. ${ }^{5} \mathrm{I}$ denote age $t=1$ as 20 years old, age $t=2$ as 25 years old, and so on. At the beginning of period 4, the agent's children are born, and four periods later (when the agent is 55 years old) the children are 20 years old and start working. The agents retire at $t=10$ (when they are 65 years old) and die by the end of age $T=14$ (before turning 90 years old). From $t=10$ (when they are 65 years old), each person faces a positive probability of dying, given by $\left(1-p_{t}\right)$. The probability of dying is exogenous and

\footnotetext{
${ }^{4}$ Although private annuity market do exist in the U.S., due to reasons such as the lack of actuarially fair price, and the existence of bequest motives, the demand for annuity is quite low.

${ }^{5}$ Data from the HRS suggests that observed inter-vivos monetary transfers are fairly small (Cardia and $\mathrm{Ng}(2000))$. Given the small size of observed inter-vivos monetary transfers, I doubt that this simplification would affect much the quantitative predictions of my model.
} 
independent of other household characteristics. The population grows at rate $n$. Since the demographic patterns are stable, agents at age $t$ make up a constant fraction of the population at any point in time. Figure 3 illustrates the demographics in the model.

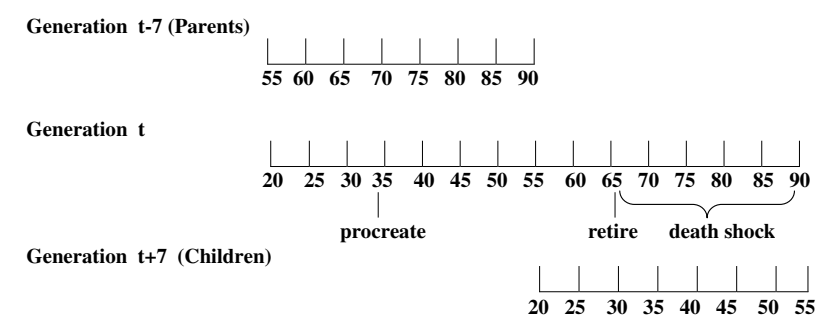

Figure 3: Demographics

\subsection{Government}

The government taxes labor earnings, capital income and estates to finance the exogenous public expenditure, $G$, and to provide Social Security benefits to the retired agents. Income from labor is taxed at a flat rate $\tau_{l} \cdot{ }^{6}$ Income from capital is taxed at a flat rate $\tau_{a}$. Government taxes bequests at the rate $\tau_{b}$ for the proportion above the exemption level $e x_{b}$.

The structure of the Social Security system is the following: Retired households receive Social Security benefits from the government each period until they die. The Social Security benefits that individuals receive are linked to their average lifetime earnings according to a piecewise linear function.

\subsection{Technology}

There is one type of good produced according to the aggregate production function $F(K ; L)=K^{\alpha} L^{1-\alpha}$, where $K$ is the aggregate capital stock and $L$ is the aggregate labor input. The final goods can be either consumed or invested into physical capital.

\footnotetext{
${ }^{6}$ In the model, labor earnings are estimated using after-tax earnings. Thus all the progressive features of the tax system are already reflected in the calibrated after-tax earnings distribution. I introduce a constant tax rate $\tau_{l}$ to balance the government budget.
} 
Physical capital depreciates at rate $\delta$. Households rent capital and efficient labor units to the representative firm each period, and receive rental income at the interest rate $r$ and wage income at the wage rate $w$.

The representative firm maintains a defined benefit plan, which is financed by contributions on each work's behalf. All workers face the same contribution rate $\tau_{D B}$. Retired households receive pensions from defined benefit plan each period until they die. The pension benefits that individuals receive are linked to their average lifetime earnings according to a piecewise linear function. ${ }^{7}$

\subsection{Consumer's Maximization Problem}

\subsubsection{Preferences}

Individuals derive utility from consumption and from bequests transferred to their children upon death. ${ }^{8}$ Preferences are assumed to be time separable, with a constant discount factor $\beta$. The momentary utility function from consumption is of the constant relative-risk aversion class given by

$$
U(c)=\frac{c^{1-\eta}-1}{1-\eta}
$$

Following De Nardi (2004), the utility from bequest $b$ is denoted by

$$
\phi(b)=\phi_{1}\left(1+b / \phi_{2}\right)^{1-\eta}
$$

The term $\phi_{1}$ reflects the parent's concern about leaving bequests to his/her children, while $\phi_{2}$ measures the extent to which bequests are luxury goods. ${ }^{9}$

\footnotetext{
${ }^{7}$ Scholz, Seshadri and Khitatrakun (2006) propose an alternative model of defined benefit plan, in which pension benefits are linked to individuals' average earnings in the past 5 year before retirement.

${ }^{8}$ Note that this form of 'impure' bequest motive implies that an individual cares about the total bequests left to his/her children, but not about consumption of his/her children.

${ }^{9}$ With the specifications, bequests are luxury goods. The scalar 1 inside the parameters ensures that the marginal utility of small bequests is bounded, while the marginal utility of large bequests declines more slowly than the marginal utility of consumption.
} 


\subsubsection{Labor Productivity}

In this economy, all agents of the same birth cohort face the same exogenous ageefficiency profile, $\epsilon_{t}$. Each worker $i$ also faces stochastic productivity shocks $y_{t}^{i}$, which follows a Markov process $Q_{y}$

$$
\ln y_{t}^{i}=\rho_{y} \ln y_{t-1}^{i}+\mu_{t}^{i}, \mu_{t}^{i} \sim N\left(0, \sigma_{y}^{2}\right) .
$$

This Markov process is the same for all households, so that there is no uncertainty over the aggregate labor endowment. The total productivity of a worker at age $t$ is given by the product of the worker's age- $t$ productivity shock and age- $t$ deterministic efficiency index: $y_{t}^{i} \epsilon_{t}$.

To capture the intergenerational correlation of earnings, I assume the parent's productivity shock at age 55 is transmitted to children at age 20 according to the following transition function $Q_{y h}$

$$
\ln y_{1}^{i}=\rho_{y h} \ln y_{h, 8}^{i}+\nu_{1}^{i}, \nu_{1}^{i} \sim N\left(0, \sigma_{y h}^{2}\right) .
$$

What the children inherit is only their first draw; from age 20 on, their productivity $y_{t}$ evolves stochastically according to $Q_{y}$.

\subsubsection{The Household's Recursive Problem}

In a stationary equilibrium, the interest rate is constant at $r$ and the wage rate is at $w \cdot{ }^{10}$ I assume that children have full information about their parents' state and children solve their decision problems after observing their parents' decisions. Children infer the size of the bequests they are likely to receive based on this information. The household's state variables are given by $\left(t, a, y, \widetilde{y}, S_{p}\right)$. The first four variables denote the agent's age, financial assets carried from the previous period, the agent's productivity, and cumulated average productivity, respectively. The last term $S_{p}$ denotes the agent's

\footnotetext{
${ }^{10} \mathrm{~A}$ formal definition of the stationary equilibrium is provided in Appendix 7.1.
} 
parent's state variables and differs in each of the following four cases.

(i) From $t=1$ to $t=2$ (from 20 to 25 years of age), the agent survives for sure until next period and does not expect to receive a bequest because his/her parent is younger than 65 .

$$
V\left(t, a, y, \widetilde{y}, a_{p}, y_{p}, \widetilde{y_{p}}\right)=\max _{c, a^{\prime}} U(c)+\beta E\left(V\left(t+1, a^{\prime}, y^{\prime}, \widetilde{y^{\prime}}, a_{p}^{\prime}, y_{p}^{\prime}, \widetilde{y_{p}^{\prime}}\right)\right)
$$

subject to

$$
\begin{aligned}
c+a^{\prime} & =\left(1-\tau_{l}\right) w \epsilon_{t} y+\left(1+r\left(1-\tau_{a}\right)\right) a \\
a^{\prime} & \geq 0, c \geq 0, \\
\widetilde{y^{\prime}} & =\left((t-1) \widetilde{y}+\epsilon_{t} y\right) / t, \\
\widetilde{y_{p}^{\prime}} & =\left((t+6) \widetilde{y_{p}}+\epsilon_{t+7} y_{p}\right) /(t+7) .
\end{aligned}
$$

At any subperiod, the agent's resources depend on asset holdings, $a$, and labor endowment, $\epsilon y$. Asset holdings pay a risk-free rate $r$ and labor receives a real wage $w$. Average productivity for children and parents accumulates according to equations (6) and (7), respectively.

(ii) From $t=3$ to $t=7$ (from 30 to 50 years of age), the worker survives for sure until the next period. However, the agent's parent is at least 65 years old and faces a positive probability of dying at any period; hence, a bequest might be received at the beginning of the next period. Let $V^{I}(t, a, y, \widetilde{y})$ and $V\left(t, a, y, \widetilde{y}, a_{p}, \widetilde{y_{p}}\right)$ denote the value function of a person whose parent is dead and alive, respectively. In the former case, $a_{p}$ and $\widetilde{y_{p}}$ are not in the state space any more.

$$
V^{I}(t, a, y, \widetilde{y})=\max _{c, a^{\prime}} U(c)+\beta E\left(V^{I}\left(t+1, a^{\prime}, y^{\prime}, \widetilde{y^{\prime}}\right)\right)
$$

subject to (4), (5), and (6). 
(9)

$V\left(t, a, y, \widetilde{y}, a_{p}, \widetilde{y_{p}}\right)=\max _{c, a^{+}} U(c)+\beta E\left(p_{t+7} V\left(t+1, a^{+}, y^{\prime}, \widetilde{y^{\prime}}, a_{p}^{\prime}, \widetilde{y_{p}}\right)+\left(1-p_{t+7}\right) V^{I}\left(t+1, a^{\prime}, y^{\prime}, \widetilde{y^{\prime}}\right)\right)$

subject to (5), (6), and

$$
\begin{aligned}
c+a^{+} & =\left(1-\tau_{l}\right) w \epsilon_{t} y+\left(1+r\left(1-\tau_{a}\right)\right) a \\
a^{\prime} & =a^{+}+b
\end{aligned}
$$

where $a^{+}$denotes the financial assets at the end of the period before receiving bequests. $^{11}$

(iii) The sub periods $t=8$ to $t=9$ (from 55 to 60 years of age) are the periods before retirement, during which no more inheritances are expected because the agent's parent is already dead by that time. The agent does not face any survival uncertainty.

$$
V(t, a, y, \widetilde{y})=\max _{c, a^{\prime}} U(c)+\beta E\left(V\left(t+1, a^{\prime}, y^{\prime}, \widetilde{y^{\prime}}\right)\right)
$$

subject to (4), (5), and (6).

(iv) From $t=10$ to $t=14$ (from 65 to 85 years of age), the agent does not work and does not inherit any more, but faces a positive probability of dying. In case of death, the agent derives utility from bequeathing his/her assets. Households receive Social Security benefits $P(\widetilde{y})$ and pensions from defined benefit plan $D B(\widetilde{y})$.

$$
V(t, a, \widetilde{y})=\max _{c, a^{\prime}} U(c)+\beta p_{t}\left(V\left(t+1, a^{\prime}, \widetilde{y}\right)\right)+\left(1-p_{t}\right) \phi(b)
$$

subject to (5) and

$$
\begin{aligned}
c+a^{\prime} & =\left(1+r\left(1-\tau_{a}\right)\right) a+P(\widetilde{y})+D B(\widetilde{y}) \\
b & =a^{\prime}-\tau_{b} * \max \left(a^{\prime}-e x_{b}, 0\right) .
\end{aligned}
$$

\footnotetext{
${ }^{11}$ Since parents are retired, average productivity for parents, $\widetilde{y_{p}}$, does not change over time.
} 


\subsection{Calibration}

The model has twenty-one parameters. I pick seventeen of them from other empirical studies and choose the remaining four parameters so that the model matches the bequest-capital ratio, the ratio of wealth to after-tax earnings, the average bequest left by people in the lowest 80 th bequest percentile, and government spending. ${ }^{12}$

I set the rate of population growth, $n$, to the average value of population growth from 1950 to 1997 from the Council of Economic Advisors (1998). The $p_{t}$ 's are the vectors of conditional survival probabilities for people older than 65 and is set to the mortality probabilities for people born in 1965 (Bell, Wade and Goss (1992)).

The deterministic age-profile of labor productivity $\epsilon_{t}$ is taken from Hansen (1993). ${ }^{13}$ The persistence $\rho_{y}$ and variance $\sigma_{y}^{2}$ of the stochastic productivity process are estimated from PSID data (Altonji and Villanueva (2002)). ${ }^{14}$ The persistence is low and variance is high because this refers to income in a 5 -year period. I take persistence $\rho_{y h}$ of the productivity inheritance process from Zimmerman (1992), and variance $\sigma_{y h}^{2}$ from De Nardi (2004).

The capital income tax $\tau_{a}$ is set to be $20 \%$ (Kotlikoff, Smetters and Walliser (1999)). The rate $\tau_{b}$ is the tax rate on estates that exceed the exemption level $e x_{b}$. I choose these two parameters from De Nardi (2004) who matches the observed ratio of estate tax revenues to GDP, and the proportion of estates that pay estate taxes. $G$ is total government expenditure and gross investment excluding transfers, and is chosen to be 18\% of GDP (Council of Economic Advisors (1998) for 1996).

The Social Security benefit is calculated to mimic the Old Age and Survivor Insurance component of Social Security system. The Social Security benefit is equal

\footnotetext{
${ }^{12}$ One period in this model corresponds to 5 years in real life, thus I adjust parameters accordingly.

${ }^{13}$ Since I impose mandatory retirement at the age of 65 , I set $\epsilon_{t}=0$ for $t>9$.

${ }^{14}$ De Nardi (2004) provides a detailed discussion of the estimation process.
} 


\begin{tabular}{clc} 
Parameters & & Calibrations \\
\hline \multicolumn{2}{c}{ Demographics } & \\
$n$ & annual population growth & $1.2 \%$ \\
$p_{t}$ & survival probability & see text \\
Endowment & & \\
$\epsilon_{t}$ & age-efficiency profile & see text \\
$\rho_{y}$ & AR(1) coefficient of 5-year productivity process & 0.85 \\
$\sigma_{y}^{2}$ & innovation of 5-year productivity process & 0.30 \\
$\rho_{y h}$ & AR(1) coefficient of productivity inheritance process & 0.67 \\
$\sigma_{y h}^{2}$ & innovation of productivity inheritance process & 0.37 \\
Government policy & \\
$\tau_{a}$ & tax on capital income & $20 \%$ \\
$\tau_{b}$ & tax on bequest & $10 \%$ \\
$e x_{b}$ & exemption level on bequest tax & 40 \\
$G$ & government spending & 0.18 \\
$P(\widetilde{y})$ & Social Security income & see text \\
$\tau_{l}$ & tax on labor income & $33 \%$ \\
Technology & & \\
$\alpha$ & capital share in National Income & 0.36 \\
$\delta$ & annual depreciation rate of capital & 0.06 \\
$D B(\widetilde{y})$ & Pension from defined benefit plan & see text \\
$\tau_{D B}$ & Contribution rate to defined benefit plan & $5.2 \%$ \\
Preference & & \\
$\eta$ & risk aversion coefficient & 1.5 \\
$\beta$ & discount factor & 0.96 \\
$\phi_{1}$ & weight of bequest in utility function & -14 \\
$\phi_{2}$ & shifter of bequest in utility function & 12 \\
\hline & &
\end{tabular}

Table 1: Parameters used in the benchmark model

to

$$
\left\{\begin{array}{ll}
0.9 \widetilde{y} w & \widetilde{y} w<0.2 \\
0.18+0.32(\widetilde{y} w-0.2) & 0.2 \leq \widetilde{y} w<1.24 \\
0.5128+0.15(\widetilde{y} w-1.24) & 1.24 \leq \widetilde{y} w
\end{array}\right\}
$$

The bend points, expressed as average earnings, and marginal rates are from Huggett and Ventura (2000). ${ }^{15}$

I take $\alpha$, the share of income that goes to capital, to be 0.36 (Prescott (1986),

\footnotetext{
${ }^{15}$ The corresponding payroll tax rate that balances the Social Security funds budget is $10.3 \%$. Since the model focuses on retirement benefits, this rate should be compared with payroll taxes excluding the Medicare and Disability Insurance (10.6\%).
} 
and Cooley and Prescott (1995)). I take depreciation to be 6\% (Stokey and Rebelo (1995)). Given the calibration for the production function, the before-tax interest rate on capital net of depreciation $r$, is $6 \%$. The defined benefit is equal to

$$
\left\{\begin{array}{ll}
0 & \widetilde{y} w<0.56 \\
0.50(\widetilde{y} w-0.56) & 0.56 \leq \widetilde{y} w<0.95 \\
0.1950+0.30(\widetilde{y} w-0.95) & 0.95 \leq \widetilde{y} w<1.24 \\
0.2820+0.23(\widetilde{y} w-1.24) & 1.24 \leq \widetilde{y} w<2.47 \\
0.5649+0.10(\widetilde{y} w-2.47) & 2.47 \leq \widetilde{y} w<3.0 \\
0.6179+0.02(\widetilde{y} w-3.0) & 3.0 \leq \widetilde{y} w<3.8 \\
0.6339+0.01(\widetilde{y} w-3.8) & \widetilde{y} w \geq 3.8
\end{array}\right\} .
$$

The bend points, expressed as average earnings, and marginal rates are chosen to mimic the holding of defined benefits wealth by lifetime earnings from HRS (Scholz, Seshadri and Khitatrakun (2006)). The flat contribution rate $\tau_{D B}$ that balances the firm's budget is $5.2 \%$.

I take the risk aversion coefficient, $\eta$, to be 1.5, from Attanasio, Banks, Meghir and Weber (1999), and Gourinchas and Parker (2002), who estimate it from consumption data. This value is in the commonly used range (1-5) in the literature.

I choose $\beta, \phi_{1}, \phi_{2}$, and $\tau_{l}$ to match the ratio of wealth to after-tax earnings of 4.9 (Hendricks (2007)), bequest-capital ratio of 0.88\% (Gale and Scholz (1994)), the average bequest left at the lowest 80th percentile of 2.78 (Hurd and Smith (2001)), and to balance government budget. ${ }^{16}$

\footnotetext{
${ }^{16}$ I use distribution for single decedents instead of the one for all decedents. Typically a surviving spouse inherits a large share of the estate, consumes part of it, and only leaves the remaining to the couple's children.
} 


\section{Numerical Results}

This section examines to what extent the quantitative life-cycle model, with incompletemarkets, earnings heterogeneity, and inheritances heterogeneity, can account for the relationship between retirement wealth and lifetime earnings and the observed large wealth difference among households with similar lifetime earnings. To answer this question, I first solve for the equilibrium. Details about computation are provided in Appendix 7.2. I then simulate 200,000 households starting from age 20 drawn from the initial distribution. I define retirement wealth to be the wealth at age 65 , and lifetime earnings to be the total earnings from age 20 to 60 , discounted to age 65 using the after-tax interest rate. I will compare results from the model with those from the PSID reported in Hendricks (2007). ${ }^{17}$ Then I decompose the effect of earnings heterogeneity and inheritance heterogeneity on wealth at retirement.

\subsection{Wealth Inequality and Lifetime Earnings}

I first look at the relationship between retirement wealth and lifetime earnings. Figure 4 shows a scattered plot of log retirement wealth and log lifetime earnings generated by the model, where I normalize values using 1994 dollars. ${ }^{18}$ The model implies a positive correlation of retirement wealth with lifetime earnings and a large dispersion in accumulated retirement wealth at all levels of lifetime earnings. In the benchmark model, as in the data shown in Figure 1, a substantial fraction of high earnings households have relatively little wealth and a significant fraction of low earnings households have a lot.

Figure 5 compares the Gini coefficients for retirement wealth for each lifetime earnings decile in the benchmark economy and in the PSID. We notice two important

\footnotetext{
${ }^{17}$ Appendices 7.4 and 7.3 show the wealth distribution for the whole economy and for households at retirement age, and the distribution of lifetime earnings.

${ }^{18}$ For explanatory purpose, I randomly pick 1500 households from the simulated sample.
} 


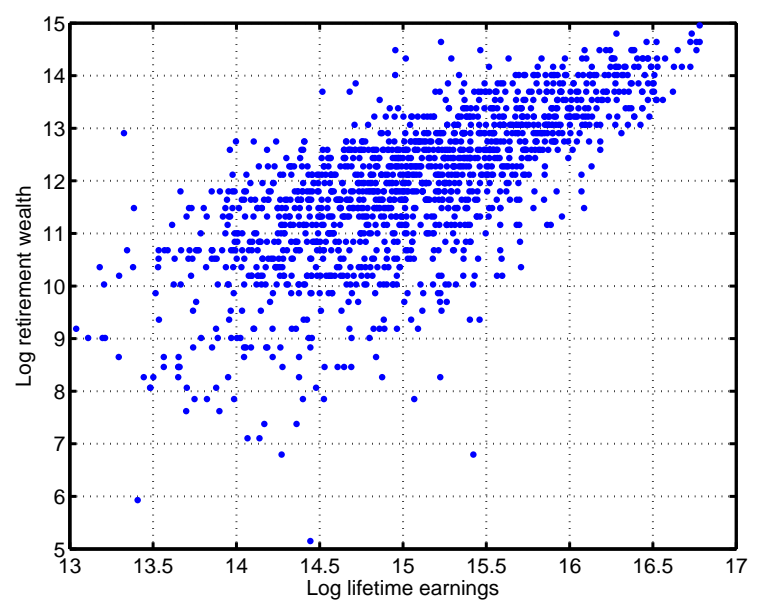

Figure 4: Retirement wealth and lifetime earnings (benchmark model)

features. First, we observe that, after controlling for age and lifetime earnings, there is still large wealth inequality in the model: The Gini coefficients in all earnings deciles in the benchmark economy are all above 0.3. Second, the degree of wealth inequality declines as lifetime earnings increases, as is observed in the data. For example, in the model the Gini coefficient is 0.66 for the 1st earnings decile and is 0.49 for the 5 th decile. The model economy matches the wealth inequality for the lower deciles quite well but underestimates wealth inequality for the highest two deciles a bit.

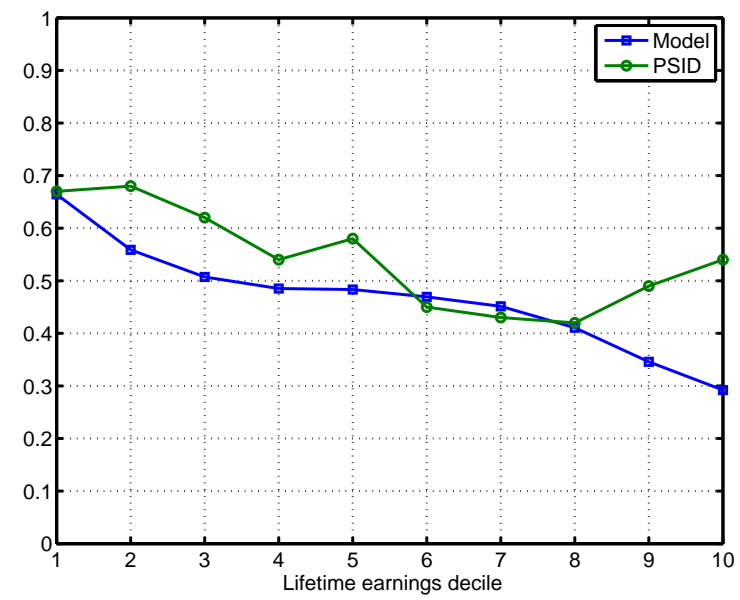

Figure 5: Gini coefficient of retirement wealth for each lifetime earnings decile (benchmark)

To measure how large are the wealth differences between earnings-rich and earnings- 
poor households, I show in Figure 6, the mean retirement wealth at each lifetime earnings decile, normalized by average household after-tax earnings. In the PSID, the earnings-rich households on average hold more wealth than the earnings-poor households. The model does a very good job in matching the mean retirement wealth observed in the data for each earnings decile. In this model, households with higher lifetime earnings will save more than households with lower lifetime earnings due to the facts that bequest is a luxury good and benefits from Social Security and from defined benefit plan follow a concave function of lifetime earnings.

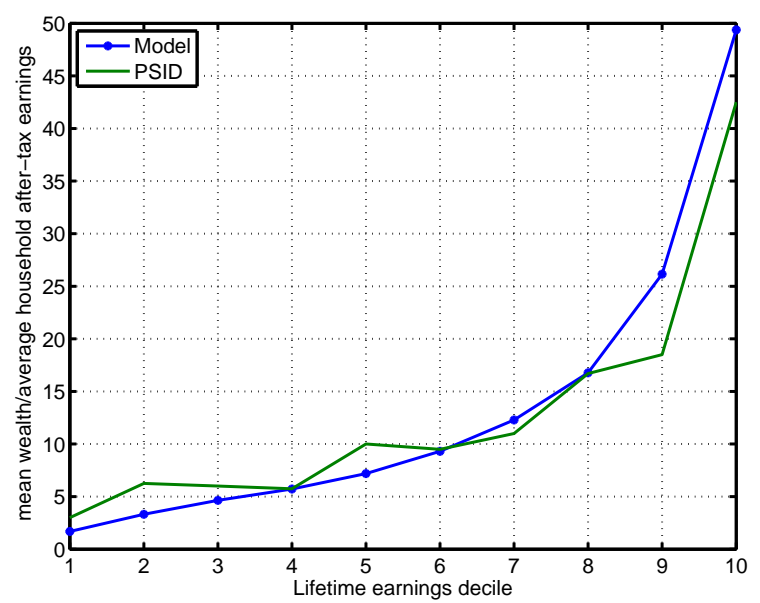

Figure 6: Mean of retirement wealth for each earnings decile (benchmark model)

To better gauge the amount of wealth dispersion at retirement generated by the model, Figures 7 compares the retirement wealth distributions for the 2nd, 5th, and 9th lifetime earnings deciles in the model with those in the data, where wealth is normalized by average household after-tax earnings. The model successfully replicates the fact that households with similar lifetime earnings hold diverse amounts of wealth. At each lifetime earnings decile, households in the lower wealth deciles hold very little wealth while households in the higher wealth deciles hold much more wealth. For example, a large fraction of households in the 2 nd earnings decile hold almost no wealth. The model generates skewed wealth distribution comparable to the data for the 2 nd and 
5th lifetime earnings deciles. Among households in the 9th lifetime earnings decile in the model, most people but the richest hold more wealth than in the data.

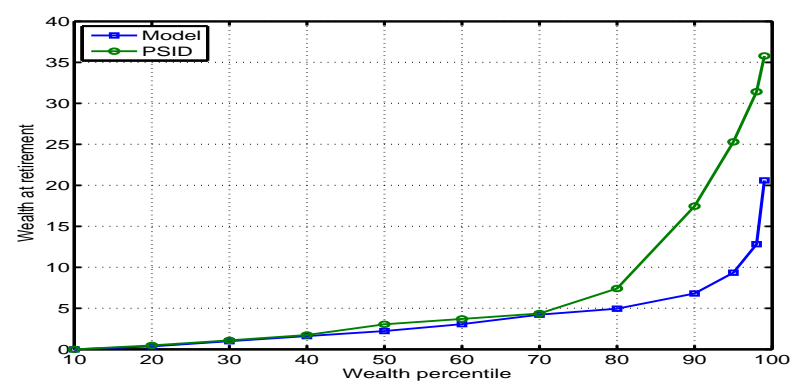

(a) 2nd lifetime earnings decile.

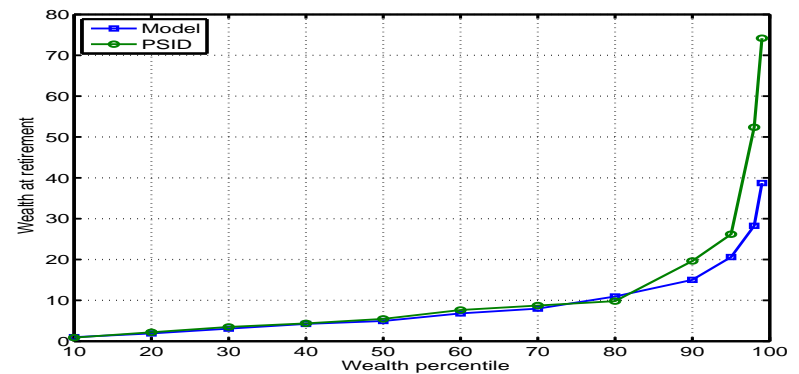

(b) 5th lifetime earnings decile.

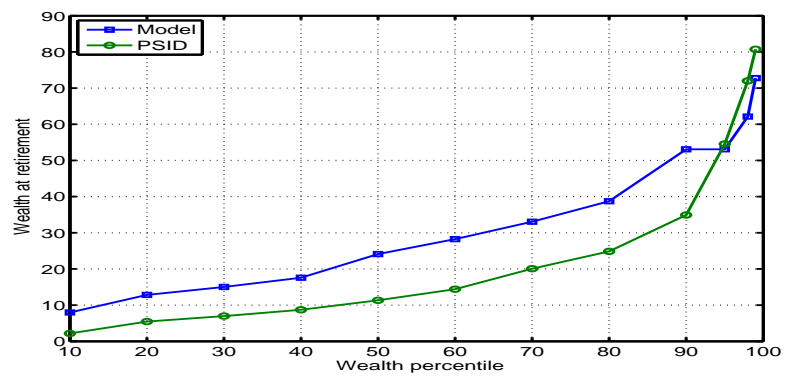

(c) 9th lifetime earnings decile.

Figure 7: Distribution of wealth (benchmark model)

Table 2 compares some statistics summarizing the relationship between retirement wealth and lifetime earnings in the PSID with those in the benchmark economy. The model with earnings heterogeneity and inheritance heterogeneity can generate large wealth heterogeneity among households with similar lifetime earnings. The correlation between retirement wealth and lifetime earnings $(0.78)$ is positive. It is slightly higher 
than that in the data (0.61). After controlling for age and lifetime earnings, the average of Gini coefficients of retirement wealth within lifetime earnings deciles (0.47) is still quite high.

\begin{tabular}{llcc}
\hline & Corr (W, E) & Mean Gini & Gini \\
\hline PSID & 0.61 & 0.54 & 0.62 \\
Benchmark & 0.78 & 0.47 & 0.62 \\
Adding measurement error & 0.77 & 0.47 & 0.62 \\
\hline
\end{tabular}

Table 2: Relationship between retirement wealth and lifetime earnings

Both earnings and wealth in the data may subject to measurement error. The fact that Venti and Wise (2000) and Hendricks (2007) obtain similar results based on alternative data sources suggests that measurement error does not affect the empirical results much. To further address the issue of measurement error, I add random noise into the sample simulated from the model. I assume that for each household, the measured lifetime earnings is the product of the simulated lifetime earnings in the model multiplied by a random variable which is normally distributed with mean 1 and standard deviation 0.1. Similarly, random noise is added to the measured wealth at retirement. The random variable added to lifetime earnings is uncorrelated with the one added to wealth. The results are show in Table 2. Adding random noise weakens the correlation between lifetime earnings and retirement wealth slightly. However, the average Gini coefficient barely changes. The reason is that, by grouping households into deciles, rather than looking at each household, some random noise averages out.

Compared with Hendricks (2007), the benchmark economy generates much larger heterogeneity in retirement wealth holding among households with similar lifetime earnings. In his model, there is a high correlation between retirement wealth and lifetime earnings (0.82) and a low average Gini coefficient (0.39). There are two important 
reasons for the differences in findings. First, in Hendricks (2007), households receive inheritance at the same age and the distribution of inheritance is approximated on a 5 point grid. As a consequence, inheritance heterogeneity is limited. Second, without voluntary bequest motives, those households who have inherited large amount consume a large part of the inheritance before retirement, reducing the wealth differences at retirement due to inheritance. In my model, households receive different amount of inheritances at different time and hold on more wealth due to operative bequest motives, which generates more heterogeneity in retirement wealth among households with similar lifetime earnings.

\subsection{The Effect of Earnings Heterogeneity}

In the benchmark model, parents and children are linked by voluntary bequests and human capital transmission. Retirement wealth inequality arises because households differ in the timing of earnings over the life cycle and in the amount and timing of inheritance received. Let us now try to understand the effect of earnings heterogeneity on the heterogeneity in retirement wealth among household with similar lifetime earnings.

A simple life-cycle model without earnings uncertainty and without borrowing constraints predicts a perfect correlation between lifetime earnings and retirement wealth. Adding earnings uncertainty and borrowing constraints breaks the prefect correlation, since the timing of positive or negative shocks differs among household with identical lifetime earnings.

Suppose two households have the same lifetime earnings, but one has positive earnings shocks when young and negative earnings shocks when old, the other has the reverse. The household with positive earnings shocks when young would save more in the earlier ages to buffer against negative earnings shocks later. Then he/she suffers 
negative earnings shocks later, he/she uses assets to finance consumption, resulting in low level of retirement wealth.

The household with negative earnings shocks when young anticipates high earnings in the future and would like to borrow to finance consumption but cannot. When he/she gets positive earnings shocks later, he/she saves most of them for retirement, and ends up holding a relatively large amount of wealth at retirement.

\begin{tabular}{|c|c|c|c|c|c|c|c|c|c|c|c|}
\hline & \multicolumn{9}{|c|}{ Age } & \multirow[b]{2}{*}{65} \\
\hline & & $20-25$ & $25-30$ & $30-35$ & $35-40$ & $40-45$ & $45-50$ & $50-55$ & $55-60$ & $60-65$ & \\
\hline \multirow[t]{3}{*}{1} & Shocks & 1 & 1 & 1 & 1 & 1 & 2 & 3 & 5 & 5 & \\
\hline & Earnings & 15 & 19 & 21 & 23 & 24 & 51 & 103 & 479 & 448 & \\
\hline & Assets & 0 & 0 & 0 & 0 & 1 & 3 & 13 & 47 & 270 & 508 \\
\hline \multirow[t]{3}{*}{2} & Shocks & 3 & 3 & 3 & 2 & 2 & 1 & 0 & 0 & 1 & \\
\hline & Earnings & 62 & 79 & 91 & 49 & 51 & 24 & 11 & 10 & 22 & \\
\hline & Assets & 0 & 7 & 21 & 40 & 40 & 40 & 34 & 25 & 13 & 3 \\
\hline \multirow[t]{3}{*}{3} & Shocks & 3 & 3 & 3 & 3 & 5 & 5 & 5 & 5 & 5 & \\
\hline & Earnings & 62 & 79 & 91 & 99 & 494 & 495 & 490 & 479 & 448 & \\
\hline & Assets & 0 & 7 & 21 & 40 & 65 & 270 & 508 & 697 & 955 & 1118 \\
\hline \multirow[t]{3}{*}{4} & Shock & 5 & 4 & 4 & 4 & 4 & 3 & 3 & 2 & 0 & \\
\hline & Earnings & 297 & 165 & 191 & 207 & 215 & 104 & 103 & 49 & 10 & \\
\hline & Assets & 0 & 105 & 144 & 197 & 270 & 317 & 317 & 317 & 270 & 168 \\
\hline
\end{tabular}

Table 3: Simulation of earnings and assets (in \$1000)

Table 3, row 1 and 2, show the simulated shocks, 5-year earnings, and assets holding at the beginning of each period for two households in the 3rd earnings decile with the same discounted lifetime earnings of $1,850,000$. Their parents have the same assets at each age so their expectations of bequests are the same. Neither of them receives any bequests. But because of the different timing of earnings, the 1st household has retirement assets of $\$ 508,000,169$ times as big as the 2nd household has $(\$ 3,000)$.

Table 3, row 3 and 4, show the simulated paths for two households in the 8th earnings decile with the same discounted lifetime earnings of $6,200,000$. The 3rd household has retirement assets 7 times as big as the 4 th household has. Households with negative earnings shocks when young and positive earnings shocks later, hold a 
relatively large amount of wealth at retirement, than households with positive earnings shocks when young and negative earnings shocks later. This holds for all earnings deciles. But the relative difference in wealth holdings is smaller among higher earnings households (row 3 vs row 4) than lower earnings households (row 1 vs row 2).

This comparison indicates that earnings heterogeneity caused by the different timing of earnings plays a more important role in generating heterogeneity on retirement wealth among households in the lower earnings deciles. The main reason is that benefits from Social Security and defined benefit plan follow a concave function of lifetime earnings. Households in all earnings deciles use assets to finance consumption when suffer negative earnings shocks later in life. Households in the lower earnings deciles, use more assets to finance consumption and carry fewer assets into retirement, since they anticipate higher pension wealth relative to current assets. On the contrary, households in the higher earnings deciles, use less assets to finance consumption and carry more assets into retirement, since they anticipate lower pension wealth relative to current assets.

\subsection{The Effect of Inheritance Heterogeneity}

Now I show the effect of inheritance heterogeneity on retirement wealth. The general equilibrium model with intergenerational links of bequests and human capital transmission endogenously determine an inheritance distribution. Table 4 reports values for the inheritance distribution implied by the benchmark economy and in the PSID (Hendricks (2007)). All inheritances received are deflated and discounted to the year where the head is 50 years old. In the PSID, inheritances are highly unevenly distributed with a Gini coefficient of 0.89 . The top $1 \%$ of the households receive $35 \%$ of all the inheritances and the top 1-5\% of the households receive $31 \%$ of all the inheritances. $50 \%$ of the households receive very little or no inheritance during their life time. The 
model generates a skewed inheritance distribution that is comparable with the data. $50 \%$ of the households receive no inheritance during their life time. The top $1 \%$ of the households receive $19 \%$ of the total inheritance, and the top $1-5 \%$ of the households receive $35 \%$ of the total inheritance.

\begin{tabular}{lllllllll}
\hline & \multicolumn{8}{c}{ Top percentile (\%) } \\
\cline { 2 - 8 } & 1 & $1-5$ & $5-10$ & $10-20$ & $20-30$ & $30-50$ & $50-100$ & Gini \\
\hline PSID & 35 & 31 & 14 & 13 & 5 & 2 & 0 & 0.89 \\
\hline Benchmark & 19 & 35 & 20 & 17 & 6 & 2 & 0 & 0.86 \\
\hline
\end{tabular}

Table 4: Lorenz curve of inheritance distribution

Modeling the transmission of earnings ability across generations and treating bequests as luxury goods are essential to match the observed skewness in the inheritance distribution. First, because the marginal utility from bequeathing is finite at zero bequests, wealth-poor households find that the marginal utility of consumption always exceeds the marginal utility of bequest. These households will choose not to leave any bequest at the last stage of their life cycle. This helps to generate a large fraction of households without any inheritance. Secondly, some large inheritances are transmitted across generations because of the voluntary bequests. Because the marginal utility of bequests declines more slowly than the marginal utility of consumption, the richest households have strong bequest motives to save some assets for their children even when very old. When there is a positive correlation between parents and children, their offspring are more likely to be earnings-rich and thus tend to leave more wealth to their offspring, thus generating a skewed inheritance distribution.

To see how the inheritances are distributed by lifetime earnings, I present in Table 5 , fraction of lifetime inheritances (in percentage) received by households in each lifetime earnings decile. In the PSID (Hendricks (2001)), inheritance is unevenly distributed across lifetime earnings deciles. Earnings-richer households receive larger inheritances. 
Households in the top 2 lifetime earnings deciles receive $41 \%$ of the total inheritance. The model generates an increasing relation between inheritance and lifetime earnings. Modeling the transmission of earnings ability across generations and a highly correlated earnings process along the lifetime is key in generating this pattern. ${ }^{19}$

\begin{tabular}{llllll}
\hline & $1-2$ & $3-4$ & $5-6$ & $7-8$ & $9-10$ \\
\hline PSID & 14 & 6 & 22 & 17 & 41 \\
Benchmark & 7 & 11 & 17 & 24 & 40 \\
\hline
\end{tabular}

Table 5: Fraction of inheritances received by lifetime earnings decile (\%)

Now I compare wealth distributions of 65-year-old households, in the 2nd, 5th and 9th lifetime earnings deciles, that did and did not inherit. This comparison can shed light on what role the inheritance heterogeneity plays in generating the heterogeneity of retirement wealth. The results are shown in Figure 8. At each decile, those who never inherited hold less wealth that those who have inherited, and the difference increases as wealth decile increases. The reason is, with operative bequest motives, those who have inherited hold a large part of the inheritances upon retirement age.

We also notice that inheritance heterogeneity plays a more important role for the higher earnings deciles: The difference between two distributions of retirement wealth increases by lifetime earnings decile. For example, those two distributions of retirement wealth for the 2 nd earnings decile differ after the 30th percentile, while those two distributions of retirement wealth for the 9 th earnings decile differ since the 10 th percentile. One reasons is that, as is shown in Table 5, there is a positive correlation between lifetime inheritance and lifetime earnings: Those who have high lifetime earnings are more likely to inherit large estates. The other reason is that, since bequest is modeled

\footnotetext{
${ }^{19}$ The monotonicity relation is weaker in the data. This might due to the fact that, in reality each married individual might receive up to 4 inheritances from his/her own parents and from the parents of the spouse. Parental wealth is imperfectly correlated since the degree of assortative matching between spouses is not strong.
} 


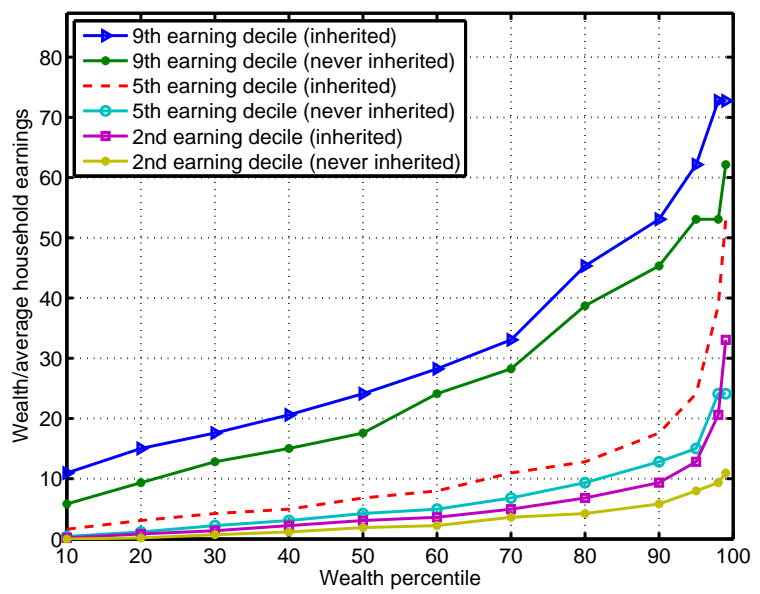

Figure 8: Distribution of wealth (benchmark model)

as a luxury good, households in the high lifetime earnings deciles, holding relatively more wealth, tend to leave more wealth to their offspring by carrying relatively more wealth towards retirement. Households in the low lifetime earnings deciles, holding relatively less wealth and thus less willing to leave bequests, consume more fraction of inheritance before retirement.

\section{Decomposition}

To understand the quantitative importance of intergenerational links of bequests and earnings ability, I run several experiments. First, I look at the model where parents care about leaving bequests to their children but there is no intergenerational transfer of productivity. Then, I look at a model where parents do not care about bequests but there is intergenerational transfer of bequest. Finally, to see how much wealth inequality can be generated by the life-cycle structure when only earnings uncertainty is activated, I turn off all intergenerational links and assume accidental bequests are equally redistributed among 50 -year-old people. ${ }^{20}$ In each case, I recalibrate $\beta$ accord-

\footnotetext{
${ }^{20}$ This is an extended version of Huggett (1996). It incorporates a realistic Social Security system and a private pension system.
} 
ingly to target the same wealth-earnings ratio.

\subsection{No Productivity Transfers}

I now look at the model where parents care about leaving bequests to their children but there is no intergenerational transfer of productivity. Table 6, row three shows that in this case the correlation between retirement wealth and lifetime earnings is 0.74 , compared with 0.78 in the benchmark economy. The Gini coefficient of retirement wealth is 0.60 , compared with 0.62 in the benchmark. The average Gini coefficient of retirement wealth within lifetime earning deciles is 0.50 , compared with 0.47 in the benchmark.

\begin{tabular}{llll}
\hline & Corr $(\mathrm{W}, \mathrm{E})$ & Mean Gini & Gini \\
\hline PSID & 0.61 & 0.54 & 0.62 \\
Benchmark & 0.78 & 0.47 & 0.62 \\
\hline Decomposition & & & \\
$\quad$ No productivity transfers & 0.74 & 0.50 & 0.60 \\
No bequest motives & 0.83 & 0.40 & 0.57 \\
$\quad$ No links & 0.85 & 0.33 & 0.54 \\
\hline
\end{tabular}

Table 6: Relationship between retirement wealth and lifetime earnings

Compared with the benchmark model, the model with bequest motives and without intergenerational transfer of productivity generates more heterogeneity of retirement wealth. The first reason is that, even without intergenerational transfer of productivity, voluntary bequest motives are enough to generate a skewed inheritance distribution (Table 7, row two). The total bequest left $(\mathrm{B} / \mathrm{K})$ is quite similar to the benchmark economy. The amount of heterogeneity in inheritances is only slightly smaller. The Gini coefficient of inheritance is 0.85 , compared with 0.86 in the benchmark economy. 
The second reason is that, with an operative bequest motive, those who inherited large estates from their parents will consume only a small part of their inheritances by the age of 65 . Thus the heterogeneity of inheritance adds a lot to the heterogeneity of retirement wealth. The third reason is that, without intergenerational link of productivity, inheritances are evenly distributed by lifetime earnings decile, which is against what is observed in the data reported in Table 5. Some households at the low lifetime earnings deciles receive unrealistically large amount of inheritances, weakening the correlation between lifetime earnings and retirement wealth.

\begin{tabular}{llllllllll}
\hline & \multicolumn{8}{c}{ Top percentile (\%) } & \\
\cline { 2 - 6 } & 1 & $1-5$ & $5-10$ & $10-20$ & $20-30$ & $30-50$ & Gini & B/K(\%) \\
\hline Benchmark & 20 & 35 & 20 & 17 & 6 & 2 & 0.86 & 0.88 \\
No Prod. Trans. & 19 & 35 & 20 & 17 & 6 & 3 & 0.85 & 0.83 \\
No Beq. Motive & 18 & 32 & 19 & 19 & 8 & 4 & 0.83 & 0.56 \\
\hline
\end{tabular}

Table 7: Lorenz curve of inheritance distribution

\subsection{No Bequest Motives}

I now look at the model where parents do not care about leaving bequests to their children but there is intergenerational transfer of productivity. Accidental bequests, if any, are inherited by the children of the deceased. Table 6 , row four reports the relevant statistics. In this case, the correlation between retirement wealth and lifetime earnings is higher than in the benchmark. Control for age and lifetime earnings reduces a larger part of the observed wealth inequality: The average Gini coefficient of retirement wealth within lifetime earnings deciles is 0.40 , compared with 0.47 in the benchmark.

This comparison shows that the unequal distribution of involuntary bequests and intergenerational transfer of earnings ability are not sufficient to generate the observed 
heterogeneity of retirement wealth. One reason is that accidental bequests are not enough to generate skewed inheritance distribution (Table 7 , row three). Without voluntary bequest motives, the total bequest left $(\mathrm{B} / \mathrm{K})$ is much smaller. The amount of heterogeneity in inheritances is also smaller. The Gini coefficient of inheritance is 0.83, compared with 0.86 in the benchmark economy. The other reason is that, without an operative bequest motive, those who have inherited large estates from their parents will consume a large part of their inheritances before retirement.

\subsection{No Intergenerational Links}

Table 6, row five shows statistics summarizing the relationship between retirement wealth and lifetime earnings in the model without intergenerational links. The correlation between retirement wealth and lifetime earnings (0.85) is much stronger than in the benchmark economy. The average Gini coefficient of retirement wealth within lifetime earnings deciles is 0.33 , compared with 0.47 in benchmark. In the model without intergenerational transfer of bequests and earnings ability, accidental bequests are equally redistributed, thus the only source of heterogeneity is the timing of earnings shocks. The comparison indicates that the timing of earnings shocks and the existence of borrowing constraints in the bonds market along are not enough to generate the observed large wealth heterogeneity among households with similar lifetime earnings.

\section{Conclusions}

Empirical studies using micro data find that there is large heterogeneity in retirement wealth among households with similar lifetime earnings, and raise doubts about the ability of a standard life-cycle model of saving behavior to reproduce the observed facts. 
I use a quantitative, incomplete-markets, life-cycle, general equilibrium model in which parents and their children are linked by voluntary bequests and by the transmission of earnings ability. I show that the model with earnings heterogeneity and inheritance heterogeneity generates an amount of heterogeneity in retirement wealth comparable to that in the data. This suggests that a properly specified life-cycle model with intergenerational transfer of earnings ability and bequests captures the fundamental determinants of households saving and wealth accumulation.

I also investigate the quantitative relevance of earnings heterogeneity, borrowing constraints, and intergenerational links, respectively, in causing heterogeneity in retirement wealth. I find that, while earnings heterogeneity and borrowing constraints are essential to generate the heterogeneity in retirement wealth among low lifetime earnings households, the existence of intergenerational links is crucial to explain the heterogeneity in retirement wealth among high lifetime earnings households.

This paper abstracts from housing. Housing is the single largest investment made by most consumers over their life time. The median household owns a house valued about twice its annual earnings. As is shown in Yang (forthcoming), abstracting from housing might bias the study of life-cycle consumption and assets accumulation behavior. It will be interesting to extend this model to look at the effect of earnings heterogeneity and inheritance heterogeneity on wealth heterogeneity in an environment with housing.

\section{$7 \quad$ Appendix}

\subsection{Definition of the stationary equilibrium}

I focus on an equilibrium concept where factor prices and age-wealth distribution are constant over time. Each agent's state is denoted by $x$. An equilibrium is described as follows.

Definition 1 A stationary equilibrium is given by government tax rates, transfers, and spending $\left(\tau_{l}, \tau_{a}, \tau_{b}, e x_{b}, P(\widetilde{y}), G\right)$; an interest rate $r$ and a wage rate $w$; defined benefit 
policies $\left(\tau_{D B}, D B(\widetilde{y})\right)$; value functions $V(x)$, allocations $c(x), a^{\prime}(x)$; and a constant distribution of people $m^{*}(x)$, such that the following conditions hold:

(i) Given government tax rates and transfers, the interest rate, the wage rate, and defined benefit policies, the functions $V(x), c(x)$ and $a^{\prime}(x)$ solve the described maximization problem for a household in a state $x$.

(ii) $m^{*}$ is the invariant distribution of households over the state variables for this economy. ${ }^{21}$

(iii) All markets clear.

$$
\begin{gathered}
C=\int c m^{*}(d x), K=\int a m^{*}(d x), L=\int \epsilon y m^{*}(d x) \\
C+(1+n) K-(1-\delta) K+G=F(K ; L)
\end{gathered}
$$

(iv) The price of each factor is equal to its marginal product.

$$
r=F_{1}(K, L)-\delta, w=\frac{F_{2}(K, L)}{1+\tau_{D B}} .
$$

(vi) The defined benefit pension budget is balanced at each period.

$$
\int I_{t>9} D B(\widetilde{y}) m^{*}(d x)=\tau_{D B} w L
$$

(vii) The government budget is balanced at each period.

$G+\int I_{t>9} P(\widetilde{y}) m^{*}(d x)=\tau_{a} r \int a m^{*}(d x)+\tau_{l} w L+\int \tau_{b}\left(1-p_{t}\right) I_{t>9} \max \left(a^{\prime}-e x_{b}, 0\right) m^{*}(d x)$

\subsection{Computation of the Model}

I discretize both the productivity and the productivity inheritance processes to sixstate Markov chains according to Tauchen and Hussey (1991). Since I want the possible realizations for the initial inherited productivity level to be the same as the possible realizations for productivity during the lifetime, I choose the quadrature points jointly for the two processes. The resulting grid points for the productivity process $y$ are [ $0.1464,0.3356,0.7002,1.4283,2.9801,6.8306]$. The transition matrix $Q_{y}$ is given by

$\left[\begin{array}{cccccc}0.6099 & 0.3537 & 0.0357 & 0.0007 & 0.0000 & 0.0000 \\ 0.1307 & 0.5327 & 0.3026 & 0.0333 & 0.0006 & 0.0000 \\ 0.0086 & 0.1974 & 0.5193 & 0.2528 & 0.02175 & 0.0001 \\ 0.0002 & 0.0218 & 0.2528 & 0.5193 & 0.1974 & 0.0086 \\ 0.0000 & 0.0006 & 0.0333 & 0.3026 & 0.5327 & 0.1307 \\ 0.0000 & 0.0000 & 0.0007 & 0.0357 & 0.3537 & 0.6099\end{array}\right]$.

\footnotetext{
${ }^{21}$ I normalize $m^{*}$ so that $m^{*}(X)=1$, which implies that $m^{*}(\chi)$ is the fraction of people alive that are in a state $\chi$.
} 
The transition matrix $Q_{y h}$ is given by

$$
\left[\begin{array}{llllll}
0.3668 & 0.4788 & 0.1426 & 0.0116 & 0.0002 & 0.0000 \\
0.0922 & 0.4240 & 0.3855 & 0.0928 & 0.0054 & 0.0000 \\
0.0134 & 0.1887 & 0.4615 & 0.2899 & 0.0454 & 0.0011 \\
0.0011 & 0.0454 & 0.2899 & 0.4615 & 0.1887 & 0.0134 \\
0.0000 & 0.0054 & 0.0928 & 0.3855 & 0.4240 & 0.0922 \\
0.0000 & 0.0002 & 0.0116 & 0.1426 & 0.4788 & 0.3668
\end{array}\right] .
$$

The transition matrices $Q_{y}$ and $Q_{y h}$ also induce an initial distribution of earnings.

The distribution of accumulated productivity at each age is approximated on a grid of 36. The state space for asset holdings is discretized. Using this grid, I can store the value functions and the distribution of households as finite-dimensional arrays.

I solve the approximated optimal consumption and saving plans recursively. Households surviving to the last period $T$ have an easy problem to solve. Based on the period $T$ policy functions, I solve the consumption and saving decisions that maximize the period $T-1$ value function. The same procedure is carried back until decision rules in the first period are computed for a large number of states.

For a given set of parameters, I solve for the steady state equilibrium as follows:

1. Given an initial guess of $\tau_{l}$.

2. Given an initial guess of interest rate $r$, use the equilibrium conditions in the factor markets to obtain the wage rate $w$.

3. Solve the value function for the last period of life for each of the points of the grid.

4. By backward induction, repeat step 3 until the first period in life.

5. Guess an initial joint distribution of parents and children at the beginning of the life cycle.

6. Given the initial distribution and policy functions, compute the associated stationary distribution of households.

7. Compute the implied joint distribution of parents and children at the beginning of the life cycle. If the distributions converge, go to step 8; otherwise go to step 5 .

8. Given the stationary distribution and prices, compute factor input demands and supplies and check whether market clearing conditions hold. If all markets clear, go to step 9. If not, go to step 2 and update interest rate $r$.

9, If the government budget is balanced, an equilibrium is found. If not, go to step 1 and update $\tau_{l}$.

\subsection{Distribution of Lifetime Earnings}

Table 8 compares values for the lifetime earnings distribution for the benchmark economy with those in the PSID (Hendricks (2007)). The model replicates the skewness of lifetime earnings distribution. This is not one of the features matched by construction, and can be seen as evidence of the ability of the model to replicate the realistic distribution of lifetime earnings. 


\begin{tabular}{|c|c|c|c|c|c|c|c|c|c|}
\hline & \multirow[b]{2}{*}{ Gini } & \multicolumn{8}{|c|}{ Top percentile (\%) } \\
\hline & & 1 & $1-5$ & $5-10$ & $10-20$ & $20-40$ & $40-60$ & $60-80$ & $80-100$ \\
\hline PSID & 0.32 & 4.4 & 9.5 & 9.1 & 15.5 & 24.5 & 18.0 & 12.3 & 6.6 \\
\hline Benchmark & 0.39 & 4.0 & 12.3 & 11.8 & 17.4 & 23.4 & 15.4 & 10.2 & 5.5 \\
\hline
\end{tabular}

Table 8: Lorenz curve of lifetime earnings (benchmark model)

Mean lifetime earnings at each decile, in the data and in the model, normalized by average lifetime earnings, is plotted in Figure 9. The model does a good job in matching lifetime earnings for each decile reported in the PSID. Lifetime earnings in the HRS are measured by the present value of Social Security earnings, and are more evenly distributed than those in the PSID. The extreme low lifetime earnings for the lower two deciles is caused by the fact that some persons in these deciles were employed in sectors not covered by the Social Security system and thus reported zero Social Security earnings. Lifetime earnings for the highest deciles in the HRS are subject to top-coding and thus are lower than in the PSID.

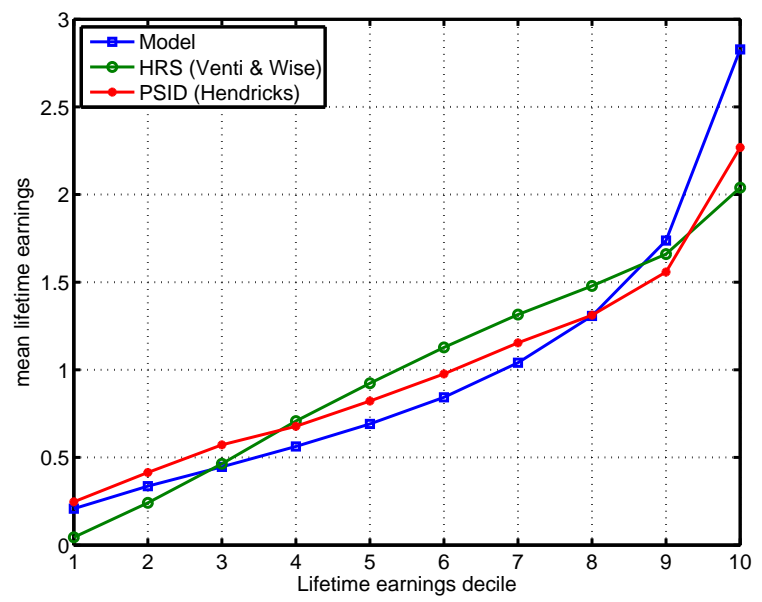

Figure 9: Mean of lifetime earnings for each earnings decile

\subsection{Wealth Distribution}

Table 9, row one, reports values for the wealth distribution for the benchmark economy. The U.S. data on the wealth distribution is from Hendricks (2007) who uses 1994 wave of PSID. In the PSID, wealth is highly unevenly distributed with a Gini coefficient of 0.76 . The top $1 \%$ of the households hold $23 \%$ of the total wealth. The model generates a skewed wealth distribution that is comparable with the data except for the top $1 \%$ of the wealth. The fraction of wealth held by the richest $1 \%$ is $12 \%$ in the model, compared with $23 \%$ in the PSID. ${ }^{22}$

\footnotetext{
${ }^{22}$ An income process that implies very large earnings risk for the highest-income earners is key in matching wealth dispersion (Castaneda, Diaz-Gimenez and Rios-Rull (2003), and Cagetti and De
} 


\begin{tabular}{|c|c|c|c|c|c|c|c|c|}
\hline & \multicolumn{7}{|c|}{ Top percentile (\%) } \\
\hline & & Gini & 1 & $1-5$ & $5-10$ & $10-20$ & $20-40$ & $40-60$ \\
\hline \multirow[t]{2}{*}{ All } & PSID & 0.76 & 22.8 & 22.5 & 14.4 & 16.8 & 16.3 & 6.4 \\
\hline & Benchmark & 0.74 & 12.1 & 26.3 & 18.5 & 19.8 & 16.8 & 5.47 \\
\hline \multirow[t]{2}{*}{ Age 65} & PSID & 0.62 & 15.7 & 18.3 & 13.8 & 17.0 & 18.8 & 10.2 \\
\hline & Benchmark & 0.62 & 7.4 & 19.4 & 16.6 & 20.9 & 20.9 & 9.7 \\
\hline
\end{tabular}

Table 9: Distribution of wealth (benchmark model)

Table 9, row two, compares values for the wealth distribution at retirement for the benchmark economy with the U.S. data. Wealth at retirement is less unevenly distributed than wealth for the whole economy both in the data and in the model. In the benchmark the Gini coefficient of wealth at retirement is 0.62 , compared with 0.74 in the whole sample. The fraction of wealth held by the richest $1 \%$ is $7 \%$ in the model, compared with $12 \%$ in the whole economy. This shows that a large amount of wealth dispersion in the economy is due to differences in age. The model generates a skewed retirement wealth distribution that is comparable with the data, expect for the top $1 \%$ of the wealth holding.

\section{References}

[1] Altonji, Joseph G., and Ulrich Doraszelski, 2005. "The Role of Permanent Income and Demographics in Black/White Differences in Wealth," Journal of Human Resources, 40 (1), 1-30.

[2] —, and Ernesto Villanueva, 2002. "The Effect of Parental Income on Wealth and Bequests," NBER Working Paper 9811.

[3] Attanasio, Orazio, James Banks, Costas Meghir, and Guglielmo Weber, 1999. "Humps and Bumps in Lifetime Consumption," Journal of Business and Economics, 17, 22-35.

[4] Bell, Felicitie C., Alice H. Wade, and Stephen C. Goss, 1992. "Life Tables for the United States Social Security Area 1900-2080," Actuarial Study No. 107, U.S. Department of Health and Human Services, Social Security Administration, Office of the Actuary.

[5] Bernheim, Douglas, Jonathan Skinner, and Steven Weinberg, 2001. "What Accounts for the Variation in Retirement Wealth Among U.S. Households?" American Economic Review, 91 , 832-857.

Nardi (2006)). My model misses this key element thus could not match the fraction of wealth held by the richest $1 \%$. 
[6] Cagetti, Marco, 2003. "Wealth Accumulation over the Life Cycle and Precautionary Savings," Journal of Business and Economic Statistics, 21 (3), 339-353.

[7] —, and Mariacristina De Nardi, 2006. "Entrepreneurship, Frictions, and Wealth," Journal of Political Economy, 114 (5), 835-870.

[8] Cardia, Emanuela, and Serena Ng, 2000. "How Important are Intergenerational Transfers of Time? A Macroeconomic Analysis," Working Paper.

[9] Castaneda, Ana, Javier Diaz-Gimenez, and Jose-Victor Rios-Rull, 2003. "Accounting for the U.S. Earnings and Wealth Inequality," Journal of Political Economy, 111 (4), 818-857.

[10] Cooley, Thomas F., and Edward Prescott, "Economic Growth and Business Cycles," In Thomas F. Cooley eds., Frontiers of Business Cycle Research (Princeton: Princeton University Press, 1995), 1-38.

[11] Council of Economic Advisors, Economic Report of the President (Washington: United States Government Printing Office, 1998).

[12] Cubeddu, Luis M., and Jose-Victor Rios-Rull, 2003. "Families as Shocks," Journal of the European Economic Association, 1, 671-682.

[13] De Nardi, Mariacristina, 2004, "Wealth Inequality and Intergenerational Links," Review of Economic Studies, 71, 734-768.

[14] Engen, Eric M., William G. Gale, Christopher Carroll, and David I. Laibson, 1999. "The Adequacy of Retirement Saving," Brookings Papers on Economic Activity, 1999, 65-187.

[15] Engen, Eric M., William G. Gale, and Cori E. Uccello, 2004. "Lifetime Earnings, Social Security Benefits, and the Adequacy of Retirement Wealth Accumulation," Working Paper.

[16] Gale, William, and John K. Scholz, 1994. "Intergenerational Transfers and the Accumulation of Wealth," Journal of Economic Perspectives, 8, 145-160.

[17] Gokhale, Jagadeesh, Laurence J. Kotlikoff, James Sefton, and Martin Weale, 2001. "Simulating the Transmission of Wealth Inequality via Bequests", The Journal of Public Economics, 79, 93-128.

[18] Gourinchas, Pierre-Olivier, and Jonathan A. Parker, 2002. "Consumption over the Life Cycle," Econometrica, 70, 47-89.

[19] Grafova, Irina, Kate McGonagle, and Frank Stafford, "Functioning and WellBeing in the Third Age", in Jacquelyn B. James and Paul Wink, ed., The Crown of Life: Dynamics of the Early Post Retirement Years (Springer Publishing Company, New York, 2006). 
[20] Guner, Nezih, and John Knowles, 2003. "Marital Instability and the Distribution of Wealth,"Working Paper.

[21] Guvenen, M. Faith, 2006. "Reconciling Conficting Evidence on the Elasticity of Intertemporal Substitution: A Macroeconomic Perspective," Journal of Monetary Economics, 53 (7), 1451-1472.

[22] Hansen, Gary D., 1993. "The Cyclical and Secular Behavior of the Labor Input: Comparing Efficiency Units and Hours Worked," Journal of Applied Econometrics, 8, $71-80$.

[23] Hendricks, Lutz, 2001. "Bequests and Retirement Wealth in the United States," Working Paper.

[24] —, 2007. "Retirement Wealth and Lifetime Earnings," International Economic Review, 48 (2), 421-456.

[25] — forthcoming. "How Important Is Preference Heterogeneity for Wealth Inequality?" Journal of Economic Dynamics and Control.

[26] Hubbard, R. Glenn, Jonathan Skinner, and Stephen P. Zeldes, 1995. "Precautionary Saving and Social Insurance," Journal of Political Economy, 103, 360-399.

[27] Huggett, Mark, 1996. "Wealth distribution in life-cycle economies," Journal of Monetary Economics, 38 (3), 469-494.

[28] Huggett, Mark, and Gustavo Ventura, 2000. "Understanding Why High Income Households Save More Than Low Income Households," Journal of Monetary Economics, 45 (2), 361-397.

[29] Hurd, Michael, and James P. Smith, "Anticipated and Actual Bequests," in David Wise, ed., Themes in the Economics of Aging (Chicago: University of Chicago Press, 2001) 357-389.

[30] Hurst, Erik, Ming-Ching Luoh, and Frank Stafford, 1998. "The Wealth Dynamics of American Families, 1984-1994," Brookings Papers on Economic Activity, 267337.

[31] Juster, F. Thomas, James P. Smith, and Frank Stafford, 1999. "The Measurement and Structure of Household Wealth," Labour Economics, 6, 253-275.

[32] Kotlikoff, Laurence J., Kent Smetters, and Jan Walliser, 1999. "Privatizing Social Security in the United States: Comparing the Options," Review of Economic Dynamics, 2 , 532-574.

[33] Krusell, Per, and Anthony A. Smith, 1998. "Income and Wealth Heterogeneity in the Macroeconomy," Journal of Political Economy, 5, 867-896. 
[34] Prescott, Edward C., 1986. "Theory Ahead of Business Cycle Measurement," Federal Reserve Bank of Minneapolis Quarterly Review, 10, 9-22.

[35] Samwick, Andrew A., 1998. "Discount Rate Heterogeneity and Social Security Reform," Journal of Development Economics, 57, 117-146.

[36] Scholz, John, Ananth Seshadri, and Surachai Khitatrakun, 2006. "Are Americans Saving "Optimally" for Retirement?" Journal of Political Economy, 114 (4), 607643.

[37] Scholz, John, and Ananth Seshadri, 2006. "Children and Household Wealth," Working Paper.

[38] Smith, James P., 1995. "Racial and Ethnic Differences in Wealth in the Health and Retirement Study," Journal of Human Resources, 30, S158-S183.

[39] Stokey, Nancy L., and Sergeo Rebelo, 1995. "Growth Effects of Flat-Tax Rates", Journal of Political Economy, 103, 519-550.

[40] Tauchen, George, and Robert Hussey, 1991. "Quadrature-Based Methods for Obtaining Approximate Solutions to Nonlinear Asset Pricing Models," Econometrica, 59, 371-396.

[41] Venti, Steven F., and David A. Wise, 2000. "Choice, Chance and Wealth Dispersion at Retirement," NBER Working Paper 7521.

[42] Yang, Fang, forthcoming. "Consumption Over the Life Cycle: How Different Is Housing?" Review of Economic Dynamics.

[43] Zimmerman, David J., 1992. "Regression Toward Mediocrity in Economic Stature," American Economic Review, 82, 409-429. 


\section{RECENT WORKING PAPERS FROM THE}

\section{CENTER FOR RETIREMENT RESEARCH AT BOSTON COLLEGE}

\section{Labor Supply Elasticity and Social Security Reform}

Selahattin Imrohorolu and Sagiri Kitao, January 2009

Evaluating Micro-Survey Estimates of Wealth and Saving

Barry P. Bosworth and Rosanna Smart, January 2009

Portfolio Choice in Retirement: Health Risk and the Demand for Annuities, Housing, and Risky Assets

Motohiro Yogo, January 2009

The Disappearing Defined Benefit Pension and its Potential Impact on the Retirement Incomes of Boomers

Barbara A. Butrica, Howard M. Iams, Karen E. Smith, and Eric J. Toder, January 2009

Retirement and Social Security: A Time Series Approach

Brendan Cushing-Daniels and C. Eugene Steuerle, January 2009

Economic Restructuring and Retirement in Urban China

John Giles, January 2009

Sources of Support for Pension Reform: A Cross-National Perspective Michelle Dion and Andrew Roberts, January 2009

The Long-Term Effect of the Divorce Revolution: Health, Wealth, and Labor Supply

Kristin Mammen, December 2008

The Response of Household Saving to the Large Shock of German Reunification Nicola Fuchs-Schündeln, November 2008

A Parsimonious Choquet Model of Subjective Life Expectancy

Alexander Ludwig and Alexander Zimper, November 2008

Risky Pensions and Household Saving Over the Life Cycle

David A. Love and Paul A. Smith, November 2008

Identifying Local Differences in Retirement Patterns

Leora Friedberg, Michael Owyang, and Anthony Webb, November 2008 